\title{
What Kind of Government Expenditure Can Reduce Rural Poverty in Indonesia's Provinces?
}

\author{
Agus Sumanto ${ }^{1 *}$, Muhammad Hasyim Ibnu Abbas $^{2}$, Farida Rahmawati ${ }^{3}$ \\ ${ }^{1,2,3}$ Universitas Negeri Malang, Malang, Indonesia \\ *Corresponding author.Email: agus.sumanto.fe@um.ac.id
}

\begin{abstract}
The rural poverty facing Indonesia's provinces is much higher than urban poverty. it needs to be seriously addressed because rural poverty is more difficult to handle than urban poverty. The purpose of this study is to analyze whether local government spending in the provinces on health, education and social protection affects the percentage of rural poverty, the poverty-gap index and the rural poverty severity index. The research period is from 2010 to 2019 with panel data from 32 provinces in Indonesia. Local government spending in one province in this study is a combination of regional government spending and provincial government spending. The result of this study is that the combined government spending in one province in the health sector does not affect rural poverty, so it is necessary to reexamine the efficiency and effectiveness of health fund distribution. Provincial government education spending has had the effect of reducing rural poverty which is something that should be exhilarating. On the other hand, social protection funds increase rural poverty, so it needs to be re-evaluated, especially in terms of determining the priority of target recipients and the effectiveness of their distribution.
\end{abstract}

Keywords: Poverty, Rural poverty, Regional government.

\section{INTRODUCTION}

Poverty is the biggest development problem faced by developing countries, including Indonesia. Countries that can eradicate poverty will automatically be classified as high-income countries. Poverty is very difficult to solve, because poverty is a multidimensional problem and is a vicious circle of poverty as has long been described by [1] and [2]. Poverty causes low income, low income causes low saving, low saving causes low capital accumulation, low capital accumulation causes low productivity.

The number of poor people in Indonesia is far more than in urban areas. Table 1 shows the percentage of poor people in urban and rural areas from 32 provinces in Indonesia from 2010 to 2019. It was recorded that the urban poor in Indonesia during the period 2010 to 2019 amounted to 8.10 percent of the total population living in urban areas. 13.65 percent of the total population living in rural areas [3].
Table 1. Average Percentage of Poor People in Urban and Rural Areas of 32 Provinces in Indonesia in 20102019

\begin{tabular}{|l|c|c|}
\hline \multirow{2}{*}{ Year } & \multicolumn{2}{|c|}{ Average Percentage of Poor People } \\
\cline { 2 - 3 } & Urban Area & Rural Area \\
\hline 2010 & 9,87 & 10,72 \\
\hline 2011 & 9,23 & 15,72 \\
\hline 2012 & 8,60 & 14,70 \\
\hline 2013 & 8,52 & 14,42 \\
\hline 2014 & 8,16 & 13,76 \\
\hline 2015 & 8,22 & 14,09 \\
\hline 2016 & 7,73 & 13,96 \\
\hline 2017 & 7,26 & 13,47 \\
\hline 2018 & 6,89 & 13,10 \\
\hline 2019 & 6,58 & 12,60 \\
\hline Average & $\mathbf{8 , 1 0}$ & $\mathbf{1 3 , 6 5}$ \\
\hline
\end{tabular}

Since rural poverty is much higher than urban poverty, efforts to address poverty in Indonesia should focus on rural poverty. Urban poverty is easier to overcome because the economic relationships between individuals are closer spatially so that the impact of economic policies spreads more rapidly for urban than rural communities. Meanwhile, for rural communities, the relatively difficult geographic location constraints 
between economic actors make the impact of government economic policies slower.

One of the ways to overcome rural poverty is to make effective and efficient government spending funds that can break the chain of poverty. Without government spending, the rural poverty chain is difficult to break because it is a multidimensional problem that is deeply rooted and entrenched. Among regional government spending, namely the provincial government and regional governments (cities and towns), which can be used to cut poverty rates are health spending, education spending and social protection spending.

Local government spending in the health sector can break the rural poverty chain. With good health, the percentage of public spending for health spending will be low compared to the total income received. Sufficient health facilities in each area, lowering the cost of the community to get health services. Then this can break the vicious cycle of poverty that ensnares a family. [4] have long stated that health is the essence of well-being and increased productivity.

Local government spending on education can also break the poverty limits that shackles rural families. With good education, it can increase the ability to increase the productivity of human resources. Prosperity that starts from a good level of education has long been adopted by the United Nations Development Program (UNDP-1994) to compile the Human Development Index (HDI) where one of the components is the level of education. The higher the education level of the population, the higher the HDI. Likewise, the proponent of broader welfare, [5] stated that with good education it will give rise to the ability of individuals to choose, the higher the ability to choose, the higher the welfare.

Likewise, with spending on social protection. Local government spending in the social protection sector will also break the poverty chain that shackles families. This spending is a direct transfer from the government without any form of remuneration and the purpose is solely for empowerment. The big role of government in this economy has long been stated by Keynes [6]. Local government spending to overcome this poverty is also the role of government in the distributive sector and also to overcome market failures that inevitably occur in an economy that relies on market mechanisms [7]. This spending policy is also a movement of the populist economy as mandated by [8], who already knows that in the realm of economic development, marginalized groups of people always occur, therefore empowerment is needed.

So this study aims to analyze whether the spending of local governments in the province in the fields of health, education and social protection affects the percentage of rural poverty, the poverty gap index and the severity of poverty. Previous research has not clearly proven that local government spending on health, education and social protection, especially for local governments of all provinces over the 10-year period, has an effect on reducing poverty in Indonesia. This poverty study, which is specific to rural poverty in all provinces in Indonesia, is useful for policy making, especially in relation to village funds and the Regional and Provincial Government Revenue and Spending Budget Plans (RAPBD).

\section{METHOD}

This study uses a quantitative approach. The study was conducted in 2010 to 2019 (10 years) by taking 32 provinces in Indonesia. So, this study uses panel data. The data used is secondary data processed from the Central Statistics Agency (BPS) and the Directorate General for Fiscal Balance, Ministry of Finance. Furthermore, the operational definition of the variable can be given as follows:

Percentage of poor people in rural areas (Y1) is the amount of people living under the poverty limits compared to the amount population of rural areas in a province. The poverty limits are the food and non-food poverty limits according to the [3].

$P_{\alpha}=\frac{1}{n} \sum_{i=1}^{q}\left[\frac{z-y_{i}}{z}\right]^{\alpha}$

Whereby :

$\alpha: 0$

$\mathrm{z}$ : poverty limits.

yi : average monthly per capita spending of people under the poverty limits $(i=1,2,3, \ldots ., q)$, yi $<z$ $\mathrm{q}:$ the amount of people who are under the poverty limits.

n : amount of population.

The Poverty Gap Index (Y2) is a measure of the average spending gap of each poor person against the poverty limits. The higher the index value, the further away the population's average spending is from the poverty limits

$P_{\alpha}=\frac{1}{n} \sum_{i=1}^{q}\left[\frac{z-y_{i}}{z}\right]^{\alpha}$

Whereby :

$\alpha=0$

$\mathrm{z}=$ poverty limits.

$\mathrm{yi}=$ Average monthly per capita spending of people under the poverty limits $(i=1,2,3, \ldots ., q)$, yi $<z$ $q=$ The amount of people who are under the poverty limits.

$\mathrm{n}=$ Amount of Population.

Meanwhile, the Poverty Severity Index (Y3) provides an overview of the distribution of spending among the poor. The higher the index value, the higher the spending inequality among the poor.

$P_{\alpha}=\frac{1}{n} \sum_{i=1}^{q}\left[\frac{z-y_{i}}{z}\right]^{\alpha}$ 
Whereby :

$\alpha=0$

$\mathrm{z}=$ poverty limits.

yi $=$ average monthly per capita spending of people

below the poverty limits $(\mathrm{i}=1,2,3, \ldots ., \mathrm{q}), \mathrm{yi}<\mathrm{z}$

$q=$ The number of people who are under the poverty limits.

$\mathrm{n}=$ amount of population

Regional Government Spending's in the Health Sector (X1) are all spending in their function to finance health and investment in the health sector carried out by a joint provincial government and all regional / city governments in one province. To produce real figures according to the population in each province, this health spending is divided by the total population projected in 2015 for each province. The result is per capita health spending.

Regional Government Spending's in the Education Sector (X2) are all spending whose function is to finance education and investment in the education sector carried out by a joint provincial government and all district / city governments in one province. To produce real figures according to the population in each province, this education spending is divided by the total population projected in 2015 for each province. The result is per capita education spending.

Regional Government Spending's in the Sector of Social Protection (X3) are all spending whose function is to finance social protection and investment in the field of social protection carried out by a joint provincial government and all district / city governments in one province. In order to produce real figures according to the population in each province, this social protection spending is divided by the total population projected in 2015 for each province. The result is per capita social protection spending.

Furthermore, the models used in this study are as follows:

$$
\begin{aligned}
& Y 1_{i t}=\beta_{1}+\beta_{2} X 1_{i t}+\beta_{3} X 2_{i t}+\beta_{4} X_{i t}+u_{i t} \\
& Y 2_{i t}=\beta_{1}+\beta_{2} X 1_{i t}+\beta_{3} X 2_{i t}+\beta_{4} X_{i t}+u_{i t} \\
& Y 3_{i t}=\beta_{1}+\beta_{2} X 1_{i t}+\beta_{3} X 2_{i t}+\beta_{4} X_{i t}+u_{i t}
\end{aligned}
$$

Whereby:

1. $\mathrm{Y} 1$ is the Percentage of Rural Poor Population in the Provinces

2. $\mathrm{Y} 2$ is the rural poverty gap index in the provinces

3. Y3 is the Rural Poverty Severity Index in Provinces

4. $\mathrm{X} 1$ is the Combined Provincial Government Spending in the health sector

5. $\mathrm{X} 2$ is the combined provincial government spending in the field of education

6. X3 is the Combined Provincial Government Spending in the field of social protection

To analyze the model, panel data regression was used. In addition, trials were conducted using the common effect, fixed effect and average effect approach, to find the best model.

\section{RESULTS AND DISCUSSION}

After statistical analysis of 320 observations $(\mathrm{t}=10$, $\mathrm{n}=32$ ), the calculation results are summarized as follows:

Table 2. Regression Analysis Result 1

\begin{tabular}{|l|r|l|r|r|}
\hline $\begin{array}{l}\text { Variable } \\
\text { (Dependent } \\
\text { variable Y1) }\end{array}$ & Coeff. & $\begin{array}{l}\text { Std. } \\
\text { Error }\end{array}$ & t-Stat & Prob. \\
\hline c & 57.69847 & 17.35863 & 3.323907 & 0.0010 \\
\hline Ln_X1 & -3.133216 & 1.750295 & -1.790107 & 0.0744 \\
\hline Ln_X2 & -8.895720 & 2.531111 & -3.514551 & 0.0005 \\
\hline Ln_X3 & 10.96536 & 1.290385 & 8.497740 & 0.0000 \\
\hline R-squared & 0.208414 & & & \\
\hline $\begin{array}{l}\text { Adjusted R- } \\
\text { squared }\end{array}$ & 0.200898 & & & \\
\hline F-statistic & 27.73278 & & & \\
\hline Prob (F-statistic) & 0.000000 & & & \\
\hline
\end{tabular}

Table 3. Regression Analysis Result 2

\begin{tabular}{|l|r|l|r|r|}
\hline $\begin{array}{l}\text { Variable } \\
\text { (Dependent } \\
\text { variable Y2) }\end{array}$ & Coeff. & $\begin{array}{l}\text { Std. } \\
\text { Error }\end{array}$ & t-Stat & Prob. \\
\hline c & 10.57143 & 4.443375 & 2.379145 & 0.0179 \\
\hline Ln_X1 & -0.668831 & 0.448032 & -1.492821 & 0.1365 \\
\hline Ln_X2 & -2.237755 & 0.647901 & -3.453853 & 0.0006 \\
\hline Ln_X3 & 2.877624 & 0.330306 & 8.711986 & 0.0000 \\
\hline R-squared & 0.237163 & & & \\
\hline $\begin{array}{l}\text { Adjusted R- } \\
\text { squared }\end{array}$ & 0.229921 & & & \\
\hline F-statistic & 32.74771 & & & \\
\hline Prob(F-statistic) & 0.000000 & & & \\
\hline
\end{tabular}

Table 4. Regression Analysis Result 3

\begin{tabular}{|l|r|r|r|r|}
\hline $\begin{array}{l}\text { Variable } \\
\text { (Dependent } \\
\text { variable Y3) }\end{array}$ & Coeff. & $\begin{array}{l}\text { Std. } \\
\text { Error }\end{array}$ & t-Stat & Prob. \\
\hline c & 3.641516 & 1.593104 & 2.285800 & 0.0229 \\
\hline Ln_X1 & -0.220638 & 0.160635 & -1.373537 & 0.1706 \\
\hline Ln_X2 & -0.897223 & 0.232295 & -3.862431 & 0.0001 \\
\hline Ln_X3 & 1.122512 & 0.118426 & 9.478573 & 0.0000 \\
\hline R-squared & 0.277257 & & & \\
\hline $\begin{array}{l}\text { Adjusted R- } \\
\text { squared }\end{array}$ & 0.270395 & & & \\
\hline F-statistic & 40.40766 & & & \\
\hline Prob(F-statistic) & 0.000000 & & & \\
\hline
\end{tabular}

The results of this analysis are very surprising for the provincial local government. As shown in tables 2,3 and 4 , health spending does not significantly affect rural poverty in the province, both on the percentage of rural poor people (Y1), rural poverty depth index (Y2) and rural poverty severity index (Y3). Education spending has a very meaningful negative impact on the percentage of rural poverty in the province (Y1), the rural poverty depth index (Y2) and the rural poverty severity index (Y3). Social protection spending has a positive and very significant effect on the percentage of rural poverty in the province (Y1), the rural poverty 
depth index (Y2) and the rural poverty severity index (Y3).

The combined health spending of district municipal governments and provincial governments does not significantly affect the percentage of poor people, the poverty gap and the severity of rural poverty. This is something good about the efficiency and effectiveness of the distribution of health funds by district / city governments and provincial governments in a province. It turns out that the amount of health spending so far has not been linked to the level of poverty that shackles the local community. This health spending is in the form of personnel spending, routine purchases of goods and services as well as capital spending in the form of building hospitals and health centers and village funds. In provinces with high rural poverty, health funds should be increased in per capita value for rural communities.

Government spending on education has a significant and negative effect on rural poverty, both in terms of percentage, depth index and severity index, which is what it should be. This finding is certainly encouraging. This means that there has been efficiency and effectiveness in the distribution of education funds in the form of routine spending, personnel spending and capital spending for the construction of educational facilities. Various kinds of educational programs, including BOS, BOPDA, undergraduate teaching in remote areas and education personnel allowances, have adjusted to the number of people in each province.

Provincial government spending in the field of social protection has a positive effect on the percentage of rural poverty, the poverty gap index and the severity index, which is something that is very unexpected. This means that the higher the social protection funds, the higher the rural poverty level. So far, government social protection funds have played no role in fighting rural poverty. So social protection spending should need to be re-evaluated, whether the distribution of social funds is right on target so that the goal is for empowerment to empower and not make the poor become dependent on government assistance. There is a possibility that social protection funds will fall to people who are actually not poor. This needs to be re-evaluated at the respective provincial level, especially in terms of the priority of the recipients of the social protection funds.

The last few decades, especially in Indonesia, the relationship between the implementation of fiscal decentralization and poverty reduction has become a hot topic. Several studies have shown different results, both in developed and developing countries, including Indonesia. The difference in results is caused by differences in the use of indicators, both indicators for measuring fiscal decentralization and differences in indicators for measuring poverty.

Supposedly, the implementation of decentralization in Indonesia can become a policy to reduce poverty.
With fiscal policy, both in terms of revenue and expenditure, the government can eliminate poverty. This is as stated by [9] that social spending and tax policy are two important aspects of government policy to address poverty and inequality problems. [10] also writes that the success of decentralization in Indonesia to reduce poverty is determined by the role of provincial and district / city governments in using regional spending to improve the quality of services to the community. [11] states that poverty reduction is also determined by the percentage of government spending.

The results of the study which show a negative relationship between government spending on poverty reduction are in line with the research of [12] in Colombia. In this study, geographic factors influence the success of direct cash transfers towards poverty reduction efforts. In line with that, the failure of direct cash transfers to the poor in rural Indonesia was due to the fact that the cash assistance was not evenly distributed, but only in certain villages. Therefore, the important factor in the distribution of financial assistance by the government to the community is not only determined by the amount, but on the accuracy of the distribution targets.

\section{CONCLUSION}

The result of this research is that the combined government spending in one province in the health area has no impact on rural poorness, this shows that the efficiency and effectiveness of health spending distribution has not been pro against rural poverty. Provincial government education spending has had the effect of reducing rural poverty, which is something that should be exhilarating. On the other hand, social protection funds increase rural poverty, so it needs to be re-evaluated, especially in terms of determining the priority of target recipients and the effectiveness of their distribution. It is possible that the amount of social protection funds for rural communities will not be able to reduce rural poverty.

\section{ACKNOWLEDGMENTS}

This study was supported and sponsored by Universitas Negeri Malang. We thank to all institution helping this study, Badan Pusat Statistik (BPS) of East Java for the supply of data.

\section{REFERENCES}

[1] R. Nurkse, Problems of Capital Formation in Underdeeveloped Countries. New York: Oxford University Press, 1961.

\author{
G. Myrdal, Economic Theory and \\ Underdeveeloped Regions. London: Allen and \\ Unwin, 1964.
}

Badan Puusat Statistik, "Percentage of Poor 
Population by Province,” Jakarta, 2020.

[4] M. . and S. C. S. Todaro, Economic development. Edisi kesembilan. Terjemahan Munandar dan Puji. Jakarta: Erlangga, 2006.

[5] A. Sen, Development as Freedom. New York: Oxford University Press, 1999.

[6] P. A. and W. D. N. Samuelson, Macroeconomics Edisi 17, Terjemahan Gretta dkk. Jakarta: PT. Media Global Edukasi, 2004.

[7] G. Mangkoesoebroto, Ekonomi Publik. Yogyakarta: BPFE, 2000.

[8] Mubyarto, Membahas Pemangunan Desa. Yogyakarta: Aditya Media, 1966.

[9] C. V. Ferrer, J. G., Rigla, F. R., Rozas, G. C., \& Figueroa, "Comparison of social spending and tax policy before and after the crisis: the cases of Spain and Chile," Glob. Stud. Journal, 6, 2014.
[10] N. \& T. Nursini, "Poverty alleviation in the contex of fiscal decentralization in Indonesia. Economics and Sociology," vol. 12, no. 1, pp. 270-285, 2019, doi: 10.14254/2071789X.2019/12-1/16.

[11] J. Martinez-Vazquez, "The impact of fiscal decentralization: Issues in theory and challenges in practice," Asian Dev. Bank, vol. 5, 2011, [Online]. Available: http://scholarworks.gsu.edu/econ_facpub/23.

[12] J. G. Ramírez, J. M., Díaz, Y., \& Bedoya, "Fiscal Decentralization and Multidimensional Poverty Reduction in Colombia: A Spatial Approach.," Inst. Soc. Econ. Res., vol. 57, no. 1, 2016. 